\title{
The Islamic Epistemology and its Implications for Education of Muslims in the Philippines
}

\author{
Abdul M. Lantong \\ Department of Islamic Studies \\ Graduate College, Cotabato City State Polytechnic College \\ Philippines \\ a_lantong@yahoo.com
}

\begin{abstract}
To reform the present Islamic educational system of the Muslims in the Philippines one has to start from epistemology. The epistemology that a society adheres to shapes the kind of education and the caliber of intellectuals it has. But, until today, Muslim educators and scholars in the Philippines have not attempted yet to go this way. Hence, this paper investigated the state of Islamic education of Muslims in the Philippines, as well as the Islamic epistemology, and its implications for educating them. The researcher used content analysis as a method of study. He gathered the data through library research and interview. The research shows that, based on Islamic epistemology, the Muslims should have a holistic education system to remedy the educational crisis they have. This system should aim for the development of righteous servants of God and His appointed khalifah, and a member of the Muslim ummah as well as the Philippine society. Also, the content of its curriculum should be integrated one as it should include revealed and acquired knowledge. The integration of the two with their various ramifications is an essential element to provide a holistic and integrated system of education which the Muslims in the Philippines are in need for them to efficiently play the role which Islam assigns for them.
\end{abstract}

Keywords-epistemology; madrassa education; Qur'an; Muslims; Philippines

\section{INTRODUCTION}

Like other Muslim minority groups that the Western colonial countries had subjected, the Muslim intellectuals in the Philippines are products of two partially opposing educational systems- the western secular education and the traditional Islamic madrassa (Ar. Singular, school) system. As a state-recognized system of education, the secular education system produced Muslim intelligentsia who are expert in their fields of specialization and qualified to serve in the government, yet devoid of knowledge of their religion since the schools where they graduated do not teach Islamic subjects. People branded them as secularists, indifferent of their religion and tradition, and even agents of secularism. On the other hand, the so-called Islamic education system, which seems to be gradually declining for many possible intervening factors, still produced some ulama (Ar. scholars) who had the opportunity to pursue higher education abroad. But although they acquired the transmitted Islamic knowledge, they seem to be isolated from the society since the lacked a background in modern scientific understanding the secular schools teach.
Due to the difference of intellectual upbringing, the two find difficulty to understand one another. Hence they are often at loggerhead, instead of cooperating for the general interest of their society.

There are some attempts to remedy the crisis. For instance, some madaris (Ar. Plural, Islamic schools) administrators opened up English department to integrate the Islamic and secular educations. Others "lobbied for Department of Education (DepEd) and Commission on Higher Education (CHED) authorization of private schools offering Islamic values in their curriculum to operate. Moreover, political leaders urged for the establishment of Islamic institutes in state universities and colleges. Thus, Mindanao State University in Marawi City opened in the 1970s the King Faizal Center for Islamic and Arabic Studies. After which, University of the Philippines in Diliman Quezon City inaugurated the Institute of Islamic Studies. Other state universities and colleges in Cotabato City, North Cotabato, South Cotabato, Zamboanga City, Sulu, and Tawi-Tawi followed suit. Aside from these, there are also private Muslimowned higher education institutions in Cotabato City, Maguindanao, and Lanao provinces offering higher Islamic education [1].

However, despite all these efforts, the desired quality of education in the Islamic schools remains relatively weak. Without derogating them, even the products of the Islamic studies programs of the state-owned universities and colleges cannot match the graduates of traditional Islamic schools abroad regarding the articulation of revealed knowledge, nor the products of the secular institutions regarding social science and much more of applied and natural sciences. In most cases, they cannot intellectually articulate the Islamic worldview, perspectives, and visions in life.

During the conduct of this research, I asked my interviewees, academic staff of the Islamic studies departments of Institute of Middle East and Asian Studies of University of Southern Mindanao, Department of Islamic Studies of Mindanao State University Gensan, and Institute of Islamic Studies, University of the Philippines about the fundamental problems of the Muslim educational system in the Philippines, to which they answered as follows: 1) lack of government support to the madrassa system, 2) poor management, and 3) narrow curriculum. So, I asked them, if we were to address these problems, where should we start? They unanimously answered that all efforts should start from 
examination of the relevance of Islamic epistemology in educational reform because it is from this where the Muslim educators had had shortcoming. Hence, the present writer decided to examine the Islamic epistemology and its implications for education of the Muslims in the Philippines. Specifically, it investigates the state of Islamic education of the Muslims in the Philippines, as well as the Islamic epistemology and its implications for the reform of this system of education. I hope that the outcome of this paper may serve as one of the basis of Muslim educators and policy makers in reforming the Muslim education in the Philippines to make them more effective partners in nation building.

\section{ISLAMIC EDUCATION IN THE PHILIPPINES}

\section{A. Madrassa Education System}

The prevalent Islamic education in the Philippines during the pre-colonial period was madrassa system, which, in our present standard, is parochial and narrow one. The usual term used to refer to teachers of this type of school is a guru (Sans. teacher). It taught students passages from the Qur'an, Arabic writing, and a little arithmetic"[2]. Other means of transmitting Islamic knowledge at the time was also 'guru' system (or tutorial) wherein parents or pupils (or murid) took a teacher whom he considered the most learned in the community due to his fame of performing supernatural power; serve him while earning knowledge the teacher imparting him. Although the system appears to be parochial, it played expertly in preserving Muslim worldview, belief system, and culture. It was from this school system where the Moro Panditas (Sans. Learned), gurus (Sans. Teacher), and perhaps ulamas, who eventually became the vanguards of Islam and Moro territory from the onslaught of the Spaniards, were produced [3].

\section{B. Abolition of Madrassa System of Education}

When the American colonizers arrived in the Philippines in 1898 , they abolished this system of education and replaced it with western secular one. The curriculum they offered was meant to colonize, westernize and secularize the Muslims. It included the teaching of western values of democracy, the formation of functional citizens and rights and responsibilities of the people. It used English as a medium of instruction. There were three levels of education- elementary, high school, and college. The public school system was free. The Americans required every child from age seven to register in classes and gave them school materials freely. They even sent some students, especially children of the ruling families, to the US as scholars to continue their studies and became experts in their profession [1]. Upon their return, the government gave them essential positions in the state. Like in other western colonized countries, these young Moros became loyal agents of American colonialists.

After the inauguration of the Commonwealth government on November 1935, with Manuel L. Quezon as President and Sergio Osmena as Vice President, the political priority of the state was the integration of the Muslims into Filipino way of life through education. The president believed that "with better education and a large dose of cultural indoctrination, the Muslims would eventually conform to the westernized ways of the new government and the Christian majority"[3]. The Commonwealth era educational system emphasized western "progressive" ideas purposely "to create a new national citizenry. It introduced rules of conduct that are entirely based on western values; it used in the schools' history books teach that the Muslims in the South, who had fought the Spaniards, were pirates and slave traders"[3].

When the United States granted independence to the Philippine Republic on July 4, 1946, the new republic also used education as a tool to integrate the Muslims into the Philippine society. To this end, the government introduced two significant projects: Commission on National Integration (CNI) and Mindanao State University (MSU). Through the CNI, the Philippine government awarded scholarship grants to the qualified and deserving Moro students who wanted to pursue higher education in the universities and colleges anywhere in the Philippines [2]. While, Mindanao State University main campus, with several branch campuses throughout the Muslim dominated areas, was established in the heart of the Muslim lands, Marawi City mandated to the integration of Muslims and other cultural communities into the national body politic.

Through this government program, many Muslim youths got a chance to pursue higher secular education. Many of them become professionals and experts in their fields. Most of them qualified to join running the affairs of the government. But, due to their secular education background, they were devoid of knowledge of Islamic worldview, tradition, belief, and values. Thus, to many Muslims, the government had successfully integrated them into the Christian society as it initially planned.

\section{Revival of Madrassa System of Education}

In the early 1950s, an Indian Muslim scholar, Maulana Abdul Aleem Siddique Al-Qaderi, made a visit to Manila. Among the impacts of this visit was the Islamic reawakening of some prominent Muslim families and leaders. Some of the economically well-off Muslim families revived the madrassa system of education. To run these madaris, the managements invited foreign Muslim scholars as teachers. Thus, two graduates of the prestigious Al-Azhar University, Muhammad Taha Omar of Arabia, and Abdulgani Sindong of Indonesia came and taught at a madrassa at Malabang, Lanao del Sur, named Kulliyatul Istihadiyah. After a year of operation, the management decided to close the school. The former moved to Jolo Sulu where he became headmaster of the Sulu Madrasah Al-Islamiyah established by Mayor Barley Abubakar, while the latter came to Cotabato on the invitation of Datu Bara Lidasan who founded a Madrassa Islamiyah at Parang, Cotabato [4].

In 1954, Kamilol Islam Society in Marawi City opened a madrassa that it incorporated into the Kamilol Islam Institute. In the following year, Dr. Domocao Alonto established a 
government-recognized school with Arabic and English Departments. Its first appointed director was Imam Iljas Ismail, an Indonesian from Acheh. In 1959, the school expanded to the collegiate level. The administration changed its name into Jamiatul Philippine Al-Islamia. In 1956, Sheikh Ahmad Bashir, after returning from the middle east, founded a madrassa now expanded into college level called Jamiat Muslim Mindanao Al-Islamie [4].

In Cotabato area, Madrassatul Rasheeda with Sheikh Omar Bajunaid, a half-blooded Arab of Yemen origin, as the headmaster, was established through the help and patronage of Congressman Luminog Mangelen of the Empire Province of Cotabato. From this school, madaris in the nearby areas of Maguindanao and South Cotabato evolved. By 1956, the first batch of 15 Rasheeda graduates began to teach at newlyfounded madaris in Dulawan, Maganoy, Cotabato, Dadiangas in South Cotabato; and Taluksangay in Zamboanga City. At about the same time, Abdulgani Sindong, through the encouragement by Hadji Pasigan, opened extension classes at the Matampay-Tukanenes Madrassa in Cotabato City [4].

In 1958, Muslim Arab missionaries continued to come and teach in Islamic schools. Muhammad Swaib from Lebanon joined the teaching force of Madrasah Dulawan. Two Arabs, Shaykh Abdulrahman Hussain, and Ahmad Mutawali followed him in 1961. The last Arab missionary to teach at Matampay Tukananes was Mohammad Farid who together with others had to leave Cotabato at the outbreak of hostilities in 1972. With the closure of Madrassa Rasheedah at Pandag, Sheikh Bajunaid decided to establish a school at LugayLugay, in Cotabato City, with English and Arabic Departments recognized by the government [4].

Today, there are many existing madaris (Islamic schools) and ma'ahid (Islamic institutes) of such a kind all over the Muslim areas to cater to the Islamic educational needs of the Muslims. But, since they are copied from the traditional madrassa system of the olden-age, these schools failed to provide a holistic education the Muslims badly need nowadays.

Based on the subjects they offer, one can conclude of what kind of products these schools could produce. They merely aimed at preparing purely religious man, with narrow understanding of concept of worship. Thus, their products have a tendency to become socially irrelevant since they lack knowledge and training in social and natural sciences, which the society also needs. For this reason, I believe that educators who were responsible for planning the educational curricula of these schools did not consider the relevance of Islamic epistemology in educating the Muslims in the modern time.

\section{THE ISLAMIC EPISTEMOLOGY}

The branch of philosophy or intellectual discourse that concerns with the theory of knowledge in Islam is called Islamic epistemology. Among others, it discusses the nature of knowledge in Islam, its source, aims and objectives, its types and branches, and how can it be acquired [5]. In this section, I will try to examine the concept of knowledge in Islam and related issues.

\section{A. The Concept of Knowledge in Islam}

The first five verses [6] of the Qur'an God revealed to Prophet Muhammad explained the concept of knowledge and its purpose. The verses indicate that knowledge (qiraah) means cognition of the reality of a thing because "human knowledge is the way how he understands the reality of a thing or existence"[7]. According to Islamic worldview, God is the originator of the reality of a thing, which the Qur'an referred to as kalimatullah (lit. word of Allah)[6]. Since the Almighty God is the originator of the truth of things, it follows that $\mathrm{He}$ alone is the source of knowledge and science.

\section{B. Hierarchy of Knowledge}

The man could attain Knowledge of God through reading (qiraah) of the book of creation (kitabul khalq). Knowledge (qiraah) of the book of creation has three levels of hierarchy. First, knowledge (qira-ah) of the book of the origin, life and final destiny of the creation (ayat al-kitab). Second, knowledge of the book of human society (ayat al-anfus); and third, knowledge of the text of the universe (ayat al-kawn) [9].

The first level of knowledge (qira-ah) was carried out by the messengers of God through the revelations they received from their Lord. This level of knowledge does not require the ability to read the inscribed alphabets or letters, but an insight that God exclusively bestowed upon His messengers who received it [7]. According to Muslim scholars, this is the reason why when Angel Gabriel commanded the prophet to read for three times; he replied that he could not read. In the part of his followers, they are required to understand, to believe with conviction, and following the teachings of the prophet Muhammad. Regarding reliability, this kind of knowledge is the most reliable one since it is derived from the most reliable sources like the Qur'an and prophet's Sunnah. Muslim scholars refer to it interchangeably as revealed knowledge, shar'i knowledge, ulum naqliyyah or transmitted knowledge [9].

The second level of knowledge pertains to the understanding of the book of human society or signs of the soul (ayatul anfus). The purpose of this reading is to extract the law ordained by God through which He governs and regulates the movement of societies- culturally, psychologically and intellectually- through the ages and time. The inquiry into the social phenomenon and human sciences is carried out by the scientists using human intellect, reason and sense organs [7]. The knowledge of this sort is called social science and humanities. The ulama classified this knowledge as rational knowledge because of the nature of its derivation through the use of human intellect and sense organs.

The third level of reading pertains to the study of the book of the universe (ayatul kawn) also known as natural phenomena. The purpose of the inquiry into the natural phenomenon is to discover and extract the natural laws ordained by God, by which He governs and regulates the 
harmonious existence of nature or the universe. The acquisition of this knowledge requires human intellect and senses, systematic study, observation, and experimentation of the natural phenomena (ayatul kawn). As clearly indicated, this inquiry is carried out by the physical scientists using human reason, mind, intellect and sense organs [7]. This knowledge is called natural science. Like the social science and humanities, the ulama classified natural science as a rational knowledge because the scientists discover or derive it through the use of human reason [8].

\section{Types and Branches of Knowledge}

Based on the above exposition, we can infer that knowledge in Islamic epistemology has two branches or types, such as: revealed or transmitted and acquired or rational knowledge. The revealed knowledge pertains to the knowledge obtained based on the divine revelation of God and the Sunnah of His messenger. This includes Islamic belief system, ethics and moral system, religious rites and symbols, principles of jurisprudence, and shari'ah. As indicated above, this knowledge is also called ulum naqliyyah or transmitted knowledge. Its acquisition, according to Imam al-Ghazali is fardh 'ain, i.e., individual obligation. Since it is fardh 'ain, it is incumbent upon every Muslim to acquire it [8].

The second type of knowledge is called acquired or rational knowledge because the scientists obtained it through the use of human reason, intellect, and sense organs. Knowledge of this kind includes social and human sciences, as well as natural and applied sciences including philosophy. According to Imam al-Ghazali, acquisition of this knowledge is fard kifayah or communal obligation [8].

The Muslim ummah should acquire the two branches of sciences because, as al-Faruqi says: "Allah (SWT) has bestowed man with reason, which is the tool required to know the world around him, to utilize it in satisfying his needs and in shouldering his responsibilities as a vicegerent. On the other hand, Divine revelation is meant to guide man toward knowledge of the aims of righteous life, of the definition of its responsibilities, and of ascertaining its components. Revelation enlightens man, despite his limited mental powers, about metaphysical concepts"[9]. So, there is no room in Islam for the so-called bifurcation of knowledge into religious and secular. As clearly shown, Islam considers these two types of knowledge as complementary.

\section{Purpose of Knowledge}

The primary goal of knowledge in the name of Allah is to know the Truth to worship correctly no one but God, the originator of reality, alone, and to be thankful to Him. The Qur'an has pointed to this purpose in many places like "And know that verily there is no God but Allah." [6] And worship, in Islamic concept, means absolute obedience to God out of one's total love of Him. And obedience to God results into harmony with the laws of existence, the laws of the universe, life and destiny which God has ordained. This then brings the man to real happiness in this world and eternity in the hereafter [7].

As a concept, there are three phenomena of worship of God: religious rites or symbols (sha'a-iriy), social (ijtima'iy), and cosmic (kawniy). The first aspect of ibadah demands knowledge of the book of revelation, which we call revealed knowledge, and following the Sunnah of Prophet Muhammad, the recipient of the revealed book. The second phenomenon of ibadah requires knowledge of the laws ordained, through which He governs and regulates the journey of the society, culture, and civilization, which is called social and human sciences. And finally, the third demands knowledge of the natural sciences to know how to utilize the potential of the universe and the nature for the sake of the pleasure of Allah [7].

So, ibadah as a purpose of God in creating man, which is also one of the primary goals of acquiring knowledge, indicates that a man must seek comprehensive, holistic, and integrative education. The reason is for a man to serve His lord best, and organize his life, individually and collectively, according to the law of His lord. Besides, he could enjoy the blessings of God He created for human use scientifically. This shows that the Muslims should base his entire life, which is supposed to be ibadah, on knowledge, and since ibadah is comprehensive, human knowledge must also be comprehensive.

\section{IMPLICATIONS OF ISLAMIC EPISTEMOLOGY ON REFORMING THE ISLAMIC EDUCATION OF MUSLIMS IN THE PHILIPPINES}

Having examined the Islamic concept of knowledge, let me now proceed to identify the impact of Islamic epistemology on reforming the Islamic education of Muslims in the Philippines. I will focus on its implications on what kind of education system the Muslims should have, what aims and objectives of this education should have, and what are to be the curriculum content of this education system.

\section{A. Educational Aims and Objectives}

As we have seen above, the Islamic system of education in the Philippines is weak, parochial and traditional. It focuses on the provision of purely religious knowledge, thinking that this is the Islamic concept of knowledge. This brought about the narrow perspective or understanding of Islam among the products that this system has produced. In the field of intellectualism, we could hardly find any Muslim intellectual who could articulate Islamic worldview and perspectives intellectually. Thus, the Islamic schools should integrate Islamic epistemology in reforming their management system, curriculum, and course offerings. Therefore, the Islamic schools, from elementary, to secondary and tertiary level should reflect in their educational goal the comprehensiveness and totality of Islamic epistemology. It should include or integrate the revealed and acquired knowledge. In the graduate and postgraduate levels, the students are expected to master or specialize any of the fields of Islamic studies that he preferred. 
By this way, the Muslim system of education will be able to produce more professionals, experts, and intellectuals who, at the same time, are righteous servants of Allah, worship Him alone in the real sense of the word, and follow the rules of Shariah in all aspects of their lives.

So, this educational system will answer the dilemma of the secular education that is only capable of preparing materialistic individuals whose primary concern is purely happiness in this world at the expense of moral and ethical values of Islam. It will also answer to the dilemma of the socalled religious education system that is capable only of producing religious individuals but intellectually incapable.

\section{B. Content of Education Curriculum}

The Islamic education system, to achieve its aims and objectives, should uphold to the balanced curriculum containing the revealed and acquired knowledge, for, in Islam, there is no contradiction between revealed and acquired knowledge, or revelation and reason. The Islamic revealed subjects, which should be taught in Arabic, should include the study of Islamic aqida, worldview, Qur'an, Sunnah, ibadah, etc. On the other hand, the acquired knowledge, which could be taught in the English language, include social science and humanities- history and civilization, sociology, anthropology, economics, political science, public administration, and international law- and natural science with its various branches. The conflict between Islamic revealed knowledge and the acquired knowledge could be avoided through teaching the latter based on Islamic principles and worldviews. This will address the issue of the bifurcation of knowledge into secular and religious.

From elementary to high school level, students should be taught with basic knowledge on revealed and acquired sciences. In the tertiary level, students will be taught with advance general knowledge- revealed and acquired- and be awarded bachelor's degree in any discipline he chooses to specialize. In the graduate and postgraduate level, the students are expected to master and become an expert in his field of specialization. By this way, this system of education could produce not only religious scholars as we have commonly see today, but including intellectuals, professionals, intelligentsia, and educators who know how to manage their mundane affairs and live in this world without sacrificing their lives in the hereafter. In other words, this education system is expected to produce real khalifah in this earth.

\section{CONCLUSION}

To conclude, the Muslim intellectuals and educators in the Philippines need to reexamine and understand the Islamic epistemology- as enshrined in the primary revealed source of Islam, the Qur'an, and explained by the Islamic scholars and intellectuals- and make it as the basis of reforming the Islamic education of the Muslims. An educational reform based on Islamic epistemology is the only way to overcome the current educational crisis of the Muslims in the Philippines. This is because Islamic epistemology demands the integration of the so-called religious and secular science which the Muslims are in need, not only to get rid of the duality of education and bifurcation of knowledge into religious and secular, but to shoulder their responsibility as righteous servants of God and khalifah in the earth.

As a sort of recommendation, to make this system of education implementable in the higher level of Muslim education, the Philippine government, through the Commission on Higher Education (CHED), may consider the creation of a separate Technical Panel for Islamic studies. Currently, Islamic Studies is parked under the discipline of social science. This Technical Panel should set the standard, approve curriculum, and monitor the implementation of higher Islamic studies or education of Muslims in the Philippines. By this way, higher Islamic studies program in the Philippines will have a chance to thrive and mature. And, the more that the Islamic education system developed, the more it could produce Muslim professionals and intellectuals who can help build a robust Filipino nation

\section{ACKNOWLEDGMENT}

The author thanks Dr. Dammang S. Bantala, the CCSPC President, for his strong support and encouragement for research works.

\section{REFERENCES}

[1] Lingga, Abhoud S. M., "Responses of Muslims in the Philippines to Modern Knowledge", An Unpublished Lecture Delivered During the First Epistemology Workshop in the Philippines Jointly sponsored by the International Institute of Islamic Thought East Asia and Mindanao State University Marawi held at the Mindanao State University, Marawi City, Philippines on April 21-22, 2011.

[2] Gowing, Peter G. Muslim Filipinos-Heritage and Horizon. Quezon City: New Day Publishers, 1979, p. 171, 184

[3] Majul, Cesar A. Contemporary Muslim Movements in Southern Philippines, Berkely: Mizan Publisher, 1985, pp.24-5.

[4] Mastura, Datu Michael, "Assessing the Madrasah as an Educational Institution: Implications for the Ummah", Unpublished Lecture. No date.

[5] Muhammad Amin, Muslim Epistemology An Analytical Appraisal of Islamization of Knowledge, $<$ www.safa.edu.pk/articles/muslimepistemology>

[6] Qur'an Surah al-Alaq: 1-5; Qur'an, Surah al-Mulk: 26; Surah Muhammad: 19.

[7] Majid Arsan al-Kilani, Philosophy of Islamic Education, Beirut: Muassasat al-Rayyan, 1998, p. 229.

[8] "The Concept of Knowledge in Islam", $<$ https://www.slideshare.net/NaimAlmashoori/the-concept-ofknowledge-in-islam $>$.

[9] Ismail R. al Faruqi, Islamization of Knowledge : General Principles and Work Plan (Herndon, VA : IIIT, 1987), pp. 51-52. 